\title{
Ultrastructural Studies of 'Kensington' Mango (Mangifera indica Linn.) Heat Injuries
}

\author{
Keryl K. Jacobi ${ }^{1}$ \\ Horticulture Postharvest Group, Queensland Department of PrimaryIndustries \\ 19 Hercules Street, Hamilton 4007, Queensland, Australia
}

Don Gowanlock ${ }^{2}$

Centre for Microscopy and Microanalysis, University of Queensland, St Lucia 4072, Queensland, Australia

Additional index words. disinfestation, scald, starch deposits, mesocarp cavitation, physiological stress

Abstract. Mature green 'Kensington' mango fruit were submerged in hot water at 46C until the fruit center reached $45 \mathrm{C}$ and then held for 30 minutes. The fruit were allowed to ripen for $\mathbf{7}$ to 10 days after the hot water treatment, and then damaged areas of skin and mesocarp tissue were prepared for observation by scanning and transmission electron microscopy. Heating-related injuries included rupturing the patterned cuticle and exocarp and exposing the underlying cells and hollow cavities (which varied in size and shape) randomly distributed within the mesocarp beneath the skin. Starch deposits still were present in the mesocarp parenchyma cells. The cell walls of damaged mesocarp parenchyma cells were convoluted and thickened in places. The injury suggested disruption of enzymes involved in carbohydrate metabolism.

Mangos are heat-disinfested in many countries to meet import-country requirements. Mexico, Florida, and Haiti treat 'Francis', 'Oro', 'Ataulfo', 'Tommy Atkins', 'Keitt', and 'Haden' with hot water for export to the U.S. mainland (Sharp, 1986; Sharp et al., 1988). External and internal injuries to a range of mango varieties have been reported following hot water and hot air treatments, including skin scalding, starchy layers forming beneath the skin, cavities within the mesocarp, and 'ricey' spots forming in the mesocarp around the seed (Esguerra et al., 1990; Jacobi and Wong, 1992). Smith and Chin (1989) found 'Haden' and 'Kensington' the most susceptible and 'Irwin' the least susceptible varieties to heat injury following hot water treatments of 42 to $48 \mathrm{C}$ for 30 to $90 \mathrm{~min}$.

To our knowledge, descriptions of such heat injuries to mango have been solely macroscopic. Our study was undertaken to examine the external and internal heat injuries to 'Kensington' mango using scanning and transmission electron microscopy.

\footnotetext{
Received for publication 17 Mar. 1994. Accepted for publication 24 Aug. 1994. We acknowledge the financial support provided by the Australian Centre for International Agricultural Research, Canberra. The cost of publishing this paper was defrayed in part by the payment of page charges. Under postal regulations, this paper therefore must be hereby marked advertisement solely to indicate this fact. ${ }^{1}$ Postharvest Physiologist.

${ }^{2}$ Research Officer.
}

then cooled in ambient air. Each treatment group consisted of a minimum of 30 fruit. After treatment, fruit were stored at $22 \mathrm{C}$ for 7 to 10 days until ripe. Tissue then was sampled for microscopic examination. Thin slices of damaged areas were excised and immediately immersed in $3 \%$ glutaraldehyde buffered in $0.066 \mathrm{~m}$ sodium cacodylate for $12 \mathrm{~h}$. The tissue was postfixed in $1 \%$ osmium tetroxide for $1 \mathrm{~h}$, dehydrated in a graded series of acetone, dried to the critical point, mounted on aluminium stubs, and sputter-coated with either platinum or gold before being viewed on a scanning electron microscope (SEM) (model 505; Philips, The Netherlands, or model 820; JEOL, Japan). Tissues for transmission electron microscopy were fixed in a similar manner to that for SEM. After dehydration in acetone, the tissues were embedded in Spurr's resin. Thin sections were stained with uranyl acetate and Reynolds lead citrate and viewed on a transmission electron microscope (TEM) (model H-7000; Hitachi, Japan, or model 400 T; Philips).

\section{Results and Discussion}

The nontreated, 'Kensington' mango fruit surface was covered by a thick, waxy, highly patterned cuticle (Fig. 1A). Pantastico et al. (1975) found that the thick and complex mango cuticle varied in thickness at various fruit development stages. The hot water treatment caused brown, damaged areas scattered over the mango surface. The patterned cuticle and exocarp of the scalded mango skin was ruptured, and underlying cells within the fruit mesocarp were exposed (Fig. 1B). The brown coloration might have been due to the action of the enzyme polyphenoloxidase (PPO), which increases in mango peel during ripening experimental heat disinfestation schedule) and
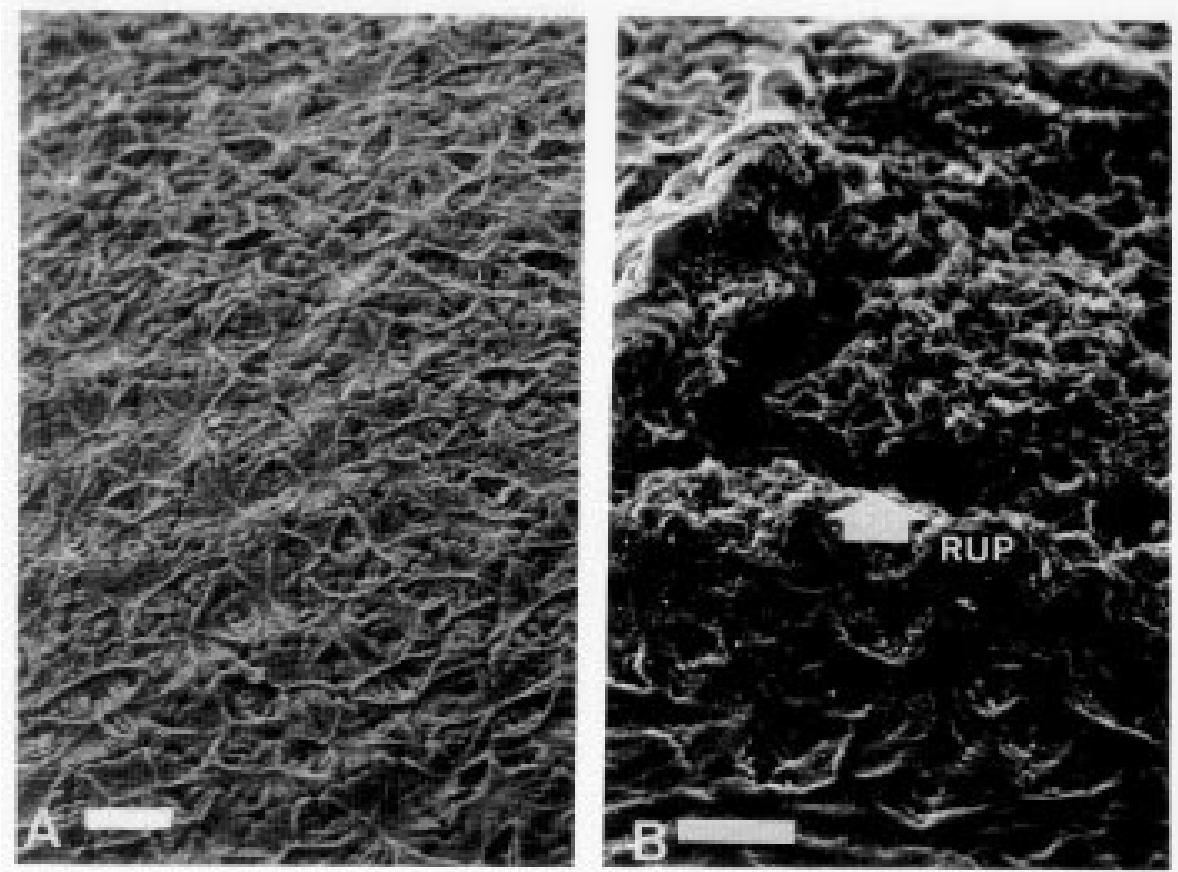

Fig. 1. Scanning electron micrographs of the patterned cuticles covering the skin of $(\mathbf{A})$ a ripe nontreated 'Kensington' mango ( $\mathrm{bar}=0.1 \mathrm{~mm}$ ) and $(\mathbf{B})$ a ripe 'Kensington' mango skin ruptured by a hot water treatment until the fruit core was at $45 \mathrm{C}$ for $30 \mathrm{~min}$ (bar $=0.1 \mathrm{~mm}$ ) (RUP, rupture of cuticle). 
(Prabha and Patwardhan, 1986). The SEM technique revealed tissue disruption in heated mango, presumably exposing cells to the PPO action, manifested as brown skin discoloration.

Nontreated ripe mango mesocarp consisted of thin-walled parenchyma cells with no starch granules (Fig. 2A). The starch granules present at the earlier stage of fruit development were metabolized into sugar during ripening

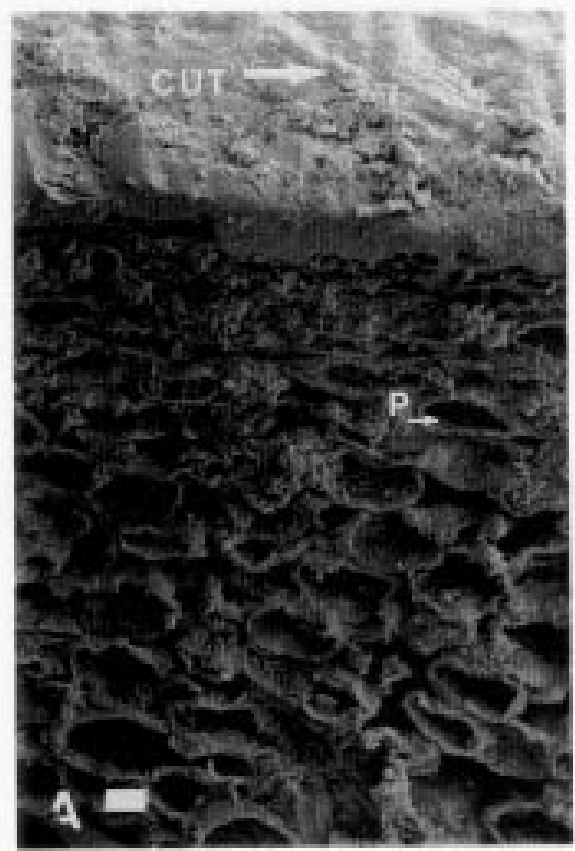

(Krishnamurthy and Subramanyam, 1973). Cavities and fissures formed in the mesocarp of heat-treated mango (Fig. 2B). The SEM showed that the cavities consisted of hollow spaces, randomly distributed within the mesocarp, 1 to $2 \mathrm{~cm}$ beneath the skin and of varying sizes and shapes. Parenchyma cells surrounding a cavity remained intact and appeared to be pushed aside throughout the tissue. Many cells

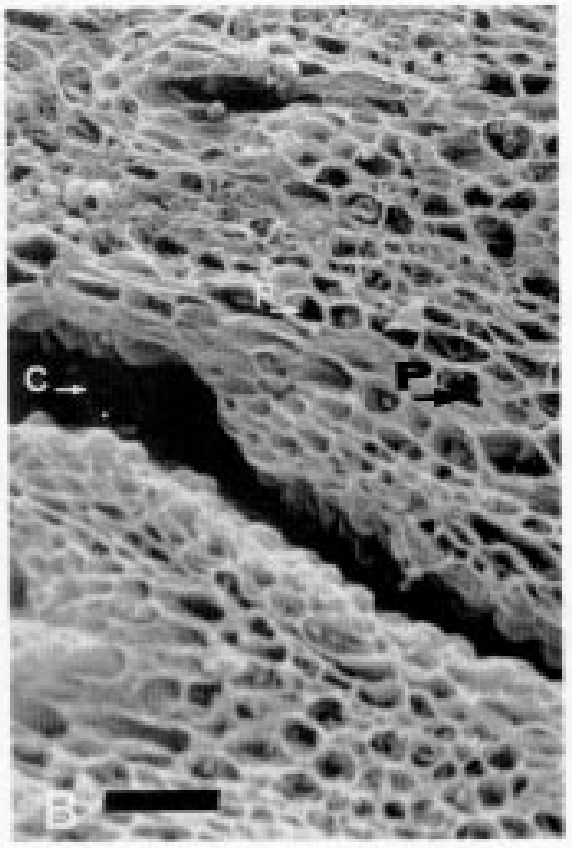

Fig. 2. Scanning electron micrographs of $(\mathbf{A})$ ripe 'Kensington' mango nontreated mesocarp $(\mathrm{bar}=0.1 \mathrm{~mm})$ and (B) ripe 'Kensington' mango mesocarp damaged by a hot water treatment until the fruit core reached $45 \mathrm{C}$ for $30 \mathrm{~min}$; cavitation evident (bar $=0.1 \mathrm{~mm}$ ) (CUT, cuticle; $\mathrm{P}$, parenchyma cell; C, cavity].
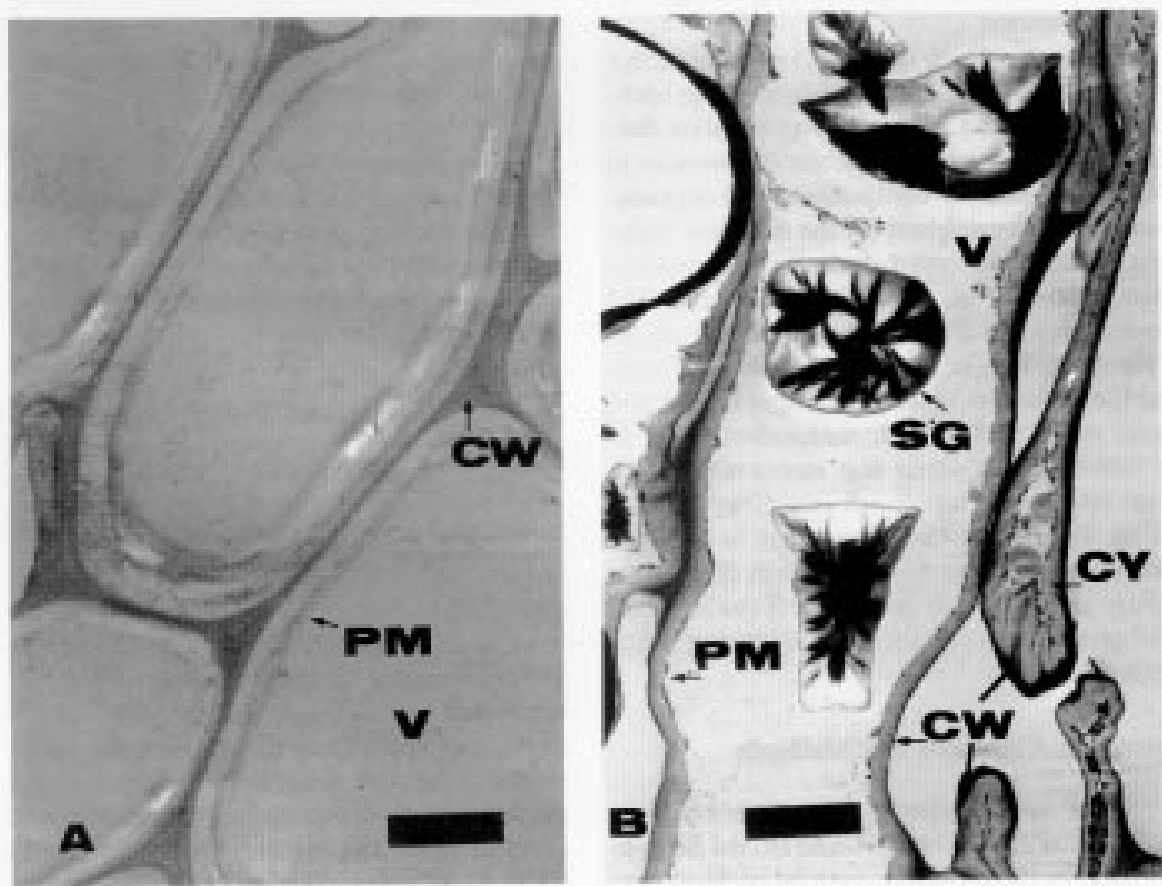

Fig. 3. Transmission electron micrographs of (A) ripe 'Kensington' mango nontreated mesocarp parenchyma cells (bar $=1.0 \mu \mathrm{m})$ and $(\mathbf{B})$ ripe 'Kensington' mango mesocarp parenchyma cells following a hot water treatment until $45 \mathrm{C}$ fruit core temperature for $30 \mathrm{~min}$; starch granules and some cell wall convolution evident $(\mathrm{bar}=1.0 \mu \mathrm{m})(\mathrm{CW}$, cell wall; $\mathrm{PM}$, plasma membrane; $\mathrm{V}$, vacuole; $\mathrm{CY}$, cytoplasm; $\mathrm{SG}$, starch granule). within the disrupted layer surrounding these cavities still had starch granules.

Mesocarp tissue from nontreated ripe fruit revealed turgid, polygonal parenchyma cells closely aligned to one another with thin walls (Fig. 3A). Cells walls were uniform in thickness, with the cytoplasm in a thin layer adjacent to the wall under a TEM. Heat-damaged mango mesocarp tissue showed parenchyma cells with cell walls convoluted and thickened in places (Fig. 3B). Starch granules were present freely within many cells. Such granules were absent in mesocarp tissue of nontreated mangos (Fig. 3A), confirming our SEM observations of the same tissue (Fig. 2).

The symptoms of mango heat injury documented in this study closely resemble the leatheriness in peaches caused by chilling injury (Luza et al., 1992). Injured peach fruit had markedly deformed internal mesocarp cells that had collapsed completely, leaving sharp protrusions of the cell walls, which became thickened. However, no evidence of separation of the plasma membrane from the cell wall or disintegration of the vacuolar membrane as in chill-injured peach cells was found in mango.

The ultrastructural changes occurring within tissues during ripening and the development of heat injury along with the redistribution of cellular components needs to be determined. Biochemical studies of the effect of hot water treatments on carbohydrate conversion could contribute to the understanding of the physiology of heated-treated fruit and the development of a nondamaging, commercial, heat disinfestation treatment.

\section{Literature Cited}

Esguerra, E.B., S.R. Brena, M.U. Reyes, and M.C.C. Lizada. 1990. Physiological breakdown in vapour heat-treated 'Carabao' mango. Acta Hort. 269:425-434.

Jacobi, K.K. and L.S. Wong. 1992. Quality of 'Kensington' mango (Mangifera indica Linn.) following hot water and vapour-heat treatments. Postharvest Biol. Technol. 1:349-359.

Krishnamurthy, S. and H. Subramanyam. 1973. Pre- and post-harvest physiology of the mango fruit: A review. Trop. Sci. 15:167-193.

Luza, J.G., R. van Gorsel, V.S. Polito, and A.A. Kader. 1992. Chilling injury in peaches: A cytochemical and ultrastructural cell wall study. J. Amer. Soc. Hort. Sci. 117:114-118.

Pantastico, E.B., J.B. Pantastico, and V.B. Cosico. 1975. Some forms and functions of the fruit and vegetable epidermis. Philip. J. Biol. 4:175-197.

Prabha, T.N. and M.U. Patwardhan. 1986. Polyphenol oxidase (PPO) and peroxidase (POD) enzyme activities and their isoenzyme patterns in ripening fruits. Acta Alimentaria 15:199-207.

Sharp, J.L. 1986. Hot-water treatment for control of Anastrepha suspensa (Diptera: Tephritidae) in mangoes. J. Econ. Entomol. 79:706-708.

Sharp, J.L., M.T. Ouye, R. Thalman, W. Hart, S. Ingle, and V. Chew. 1988. Submersion of 'Francis' mango in hot water as a quarantine treatment for the West Indian fruit fly and the Caribbean fruit fly (Diptera: Tephritidae). J. Econ. Entomol. 81:1431-1436.

Smith, E.S.E. and D. Chin. 1989. Hot water dipping as a disinfestation treatment against the fruit fly Dacus aquilonis (May) (Diptera: Tephritidae) in mangoes. Acta Hort. 291:389-403. 